\title{
A Nationless State? Malta, National Identity and the EU
}

\author{
GODFREY BALDACCHINO
}

This article discusses the relationship of Malta with the European Union in the light of Malta's status as an example of a 'nationless state'. The article first develops the relevance of this underresearched concept by locating it within the discussion of postcolonial, small island nationalism. It then provides a historical critique of the emergence of the Maltese nationless state and of its various integrationist attempts with France, Italy, Britain and, most recently, the EU. Finally, the article explores the possible dialectics of an emerging nationalism with an entrenched two-party political system and its totalising discourse.

After two years of negotiations, a comprehensive package for Malta as a prospective member of the European Union (EU) is taking shape. When he visited Malta early in 2001, Enlargement Commissioner Verheugen advised the Maltese people to allow more time before they decided either in favour or against EU membership.' Deciding on membership is a thorny issue, since Malta is the EU candidate state with the strongest anti-EU sentiment, with the possibility of a negative result in an EU accession referendum likely to be held early in 2003.' What is taking shape is not just the emergence of a package of obligations, but perhaps the birth pangs of a long overdue national conscience.

\section{ENTER THE NATIONLESS STATE}

This article will attempt to assess the unfolding relationship of Malta with the European Union in the light of Malta's status as an example of a 'nationless state'. Malta's current rapprochement with the EU affords an intriguing opportunity for the late development of a, hitherto elusive, national identity. The argument is structured in three parts. The first reviews the theoretical underpinnings of the tensions between statehood and nationhood, identifying the category of the 'nationless state' and setting out 
its relevance to the discussion by locating it within a consideration of postcolonial nationalism in island territories. This is followed by a brief analysis of the emergence of the Maltese nation, the formative role of the Catholic Church and political parties in this evolution and the unfolding Malta-EU relationship over the last 30 years. The article concludes by analysing the consequences of the tension between Maltese nationalist (or even pseudonationalist?) discourse and the well-entrenched party political system.

This approach belies the author's concern with the absence of a nationalist sentiment in Malta. It may be criticised for seeking to invent nationalism where it does not, and perhaps should not, exist:"' is the 'Maltese nation' merely an 'imagined political community', in the literal sense?' The historical and geographical conditions of the Maltese islands appear conducive to the development of a unitary cultural frame of reference; and other small islands in a similar predicament have certainly done so. ${ }^{5}$ However, irredentist movements in Malta have taken the upper hand in local politics, paradoxically utilising jurisdictional capacity - and, since political independence in 1964 , the very apparatus of sovereignty - to facilitate the incorporation of Malta into a larger entity. Only the intended beneficiary of such an incorporation has changed in the course of 200 years of history: first France, then Britain or Italy, and now the EU.

\section{STATEHOOD AND NATION}

What the nation is may be a state of mind. One cannot discount that the desire for, and pursuit of, self-government and authentic identity is perhaps the most powerful force in modern history. However, the territoriality over which government is exercised does not always fit snugly with the range of people who see themselves as rightful cohabitants and co-citizens. The disequilibrium between statehood and nation is today at the heart of much political instability, tension and civil strife. There are, first of all, communities that consider themselves nations, but which are not recognised as such by others or are not granted the legitimacy and mechanisms of fullyfledged states. These are 'nations in waiting', 'proto-nations', 'nations without states' or 'non-state nations'? These include 'Kurds, Basques, Armenians, Palestinians, Québeçois, Cree Indians, Scots, Welsh, Cornish ... many others'. "What binds them together is that each somehow demonstrates a 'national conscience'. These assemblages are being given increasing recognition in the devolutionist strategies of governments threatened by actual or potential secession (Euskadi-Spain; Corsica-France; Padania-Italy; Quebec \& Nunavut-Canada; or Cechnya-Russia), as well as by the strengthened regional policy of the $\mathrm{EU}$ in the "Europe of the Regions'." 
There are, on the other hand, 'cleft states' embodying an uncomfortable, at times tempestuous, collection of two or more distinguishable, often ethnic, groups." Here, loyalty to the clan/nation usually assumes priority over that to a typically weak state and its imperfect structures, imposed as the latter may have been through rigged elections, war, conquest or colonisation. Sri Lanka, Nigeria, Rwanda and Fiji comprise a diverse set of such 'cleft states', with Madagascar (for some time this year) an emerging candidate.

What is proposed here is a distinct, third category of such disjuncture, which does not deal with the relationship and overlap of statehood and nationhood, but with the existence of statehood without a defined sense of nationhood. There is no interplay here between different ethnic groups within the same state, or between states; no 'minority-majority' relationship; no conflict between a dominating and a dominated ethnic group. This is the specific plight of "states without nations'." Evidence of such "nationlessness" in sovereign states is difficult to discern, all the more so since states are somehow expected, and expect themselves to be nations. The political and ideological apparatus of any such state will certainly endeavour to promote the notion that the nation does exist - even though that may be an exercise in the construction of a fallacy. Still, history is replete with examples of notional states created by default or design.

Territories harbouring no territorial or identity conflicts between indigenous peoples or ethnic groups may include small island states. Various islands have found themselves far away from metropolitan centres that did not administer, but acculturalised the inhabitants of their island colonies. Such insular territories were often eventually obliged to accept distinct sovereignty almost by default, even in view of the absence of a larger, and practical, political settlement." This category comprises various small island jurisdictions, which have not been colonised but created by colonialism. We are not talking of societies where the natives have been supplanted by immigrant settlers, but rather where the natives are the settlers. ${ }^{13}$ These conform to Naipaul's strikingly vicious labels of 'manufactured societies, labour camps, creations of empire'." They may indeed be states. and take pains to proclaim themselves as such, with all the panoply and ceremony usually associated with statehood. However, even after long years of political independence, they may still be searching for a sense of authentic nationhood. Referring to Naipaul again, they may have been fated, or fortunate, in always having meant to form part of something larger, ${ }^{15}$ typically a colonial master turned patron. Historically, they may have much in common with small territories that stubbornly refuse to entertain independence.

Indeed, a tangible demonstration of the relative absence of a national conscience would be the indifference, if not outright hostility, to political 
sovereignty. Examples include the Seychelles; ${ }^{16}$ Anguilla; $;{ }^{17}$ a variety of scattered small island dependencies of Britain ${ }^{18}$ and the Netherlands; ${ }^{19}$ or the integration and absorption into a larger nation in the case of the départements d'outre mer of France ${ }^{20}$ One may also mention the enosis of the two Cypriot communities with either Greece or Turkey. Such examples go against the conventional wisdom, which equates insularity with community and assumes the existence of an island-based and island-driven national identity that finds its obvious and legitimate contemporary expression through political sovereignty. A typical claim would be that the geographical isolation and compact socio-political universe of small island states are "likely to promote feelings of fellowship and a sense of community'. ${ }^{21}$ Other commentators are more critical and qualify island identity in accordance to current geo-political forces and perceptions. Thus, according to Jean Didier Hache, the reference to one's predicament as an insular one in the case of citizens of island territories invariably refers to the deliberate placing of that island in a potentially subordinate or peripheral power relationship, with a major player, 'centre' or 'mainland' beyond:

insularity tends to be the result of a process of economic, social, cultural and political peripheralisation that has affected these populations, a process made more acute, or more apparent, by their insular condition; ... insularity should be seen, first and foremost, as a political phenomenon, and especially as the product of evolving centre/periphery relationships."

Thus, an island people's identity as such, and the emergence of an island nation-state, need not be automatic, but should be seen as the outcome of a formative cultural process that involves a struggle, even if only psychological or virtual, with an external 'other'. In the absence of any such referent, a sovereign island state may have little inducement towards developing a territorially based nationalism.

\section{MALTA: A NATIONLESS STATE?}

Primordial and secondary elements of identity include ethnicity, language, religion, cultural values and customs, a distinct historical self-view and a sense of territorial bonding. ${ }^{23}$ Malta would certainly appear to qualify on all these counts to the untested eye. With a long history of colonisation of at least five millennia, the Maltese come across today as a people with no internal racial tensions, united by the Catholic faith, speaking a unique language and living on definitively precise limestone blocks comprising just 316 square kilometres. Yet one may hazard to proclaim that Malta today is a 'nationless state', a 37-year-old sovereign unit where the nation is yet to 
be formed. It is easy to condone references to a monolithic 'Maltese Society' ${ }^{24}$ Such a definitive term fails to render justice to sub-cultural traits amongst the Maltese ${ }^{25}$ and fails to take account of the existence of - albeit very small - minority groups, such as Indian entrepreneurs or retired British pensioners. ${ }^{2 n}$ But history, acute population density and the pervasive socialising powers of Catholicism have tended to erode many cultural differences over time. It would, therefore, be fair to define Malta as a "crossroads island' with a 'cosmopolitan and polyglot' population reflecting the 'ethnic and linguistics mixtures of Phoenician, Arab, Sicilian and British colonial influences'. ${ }^{27}$ Other than in extreme cases, ethnicity is not a relevant analytical category to contemporary Malta.

The Maltese Islands certainly qualify as pioneers in imaginative statecraft, having been held as a distinct fiefdom by Aragonese and Castellan landlords in the late Middle Ages and subsequently having spent a long period (1530-1798) as the seat of the Knights of St John of Jerusalem, a theocracy that ruled over Malta in an interesting chivalric and pioneering version of the European Union. Specific nation-building initiatives as such were not, however, encouraged by the ruling élite, including the Maltese aristocracy of lawyers, medics and priests, a comprador bourgeoisie even in a cultural sense that traditionally and linguistically associated itself readily with Italy. Indeed, the eventual unity of Malta with Italy was a policy pursued in the early to mid-1900s by various exponents of the strong Nationalist (sic) Party (NP), ${ }^{28}$ and several NP leaders, many with declared fascist sympathies, were interned in Uganda for the duration of the Second World War, when Malta served as the critical fulcrum of the British war effort in the Mediterranean theatre. The legitimation of Maltese as an official language by the 1930s was a largely unintended outcome of the struggle for cultural (and political) supremacy between Italian and English, the latter being the upcoming language of the new middle mercantile and administrative classes during the period of British rule (1800-1964). ${ }^{29}$ There was absolutely no struggle for political independence - granted by Britain on 21 September 1964 - and its pursuit was again a 'second best' option after attempts to secure full integration by the Malta Labour Party (MLP) with Britain had failed in the late 1950s. Premier Mintoff did negotiate successfully to extend the date of the eventual dismantling of the British Military Base in Malta, the mainstay of the local 'fortress' economy, up to March 1979.

This is not to argue that Malta has had no nationalist birth pangs. ${ }^{30}$ An undercurrent of anti-colonial resistance had been active in Malta certainly since the late Middle Ages." Even before Malta was officially declared a British colony by the Treaty of Amiens in 1814, there were already agitations for representative rights and institutions by members of the 
Maltese clerico-professional élite. The spontaneous 'bread riots' of June 1919 did bring about a reassessment of the assumed loyalty of the Maltese and paved the way to the first self-governing constitution in 1921. Still, the one 'national' rebellion to speak of in two centuries occurred during the brief French occupation (1798-1800). Then, the Maltese rose against their new occupiers when the French started despoiling the local Catholic churches of their gold and silver artifacts. Interestingly, it was in favour of the interests of the local Catholic Church that the Maltese rebelled; and clerics played a key role in organising the uprising.

The power of the Catholic Church in Malta must not be underestimated, even today. The Catholic Church and its ethos and ceremonies remain today the closest to a national Maltese symbol. In spite of evident secularisation, around 70 per cent of the population attend weekly mass regularly; a third of all young Maltese complete their schooling in church schools; and most young Maltese have to attend long hours of 'doctrine' to qualify for the sacrament of confirmation. There is one church or chapel for every square kilometre on the small archipelago, and many remain in use. Most of the arts - including music, drama, sculpture, painting, folk stories - are patronised substantially by the church and have explicit religious themes. 70 per cent of the Maltese identify commitment to religious values as their top priority in life. ${ }^{32}$ The decisions of the Catholic Church's ecclesiastical tribunal in declaring the annulment of marriages or otherwise are recognised in the civil courts. Malta remains the only European country that has not legalised divorce. Malta's long years as a Catholic fiefdom facilitated the emergence of a local ecclesiastical hierarchy that exercised strong political and cultural influence. This, in turn, has bred a national mind-frame strongly determined by religious precepts of propriety and morality. Thus, non-Christians have been historically relegated to the status of "heathens" or 'infidels', and in this way have served as a convenient 'other' to the Maltese. The contrast aggrandises the role of the Catholic faith and church in moulding Maltese national identity, albeit in non-secular fashion.

The hegemony of the Catholic Church in Malta was dented most seriously in its drawn out confrontation with the Malta Labour Party during the 1960s. The Church then did not support the MLP's campaign for Malta's integration with Britain, for fear that its interests would not be safeguarded and would eventually be croded in an Anglican British state. The Church may also have had serious concerns that Dom Mintoff, the charismatic MLP leader, had Communist tendencies which - given his well-publicised overtures to China, North Korea and the Soviet Union - might eventually translate Malta into a secular state where the Catholic Church would lose out. In a bitter showdown between Church and political party in 1961, the top MLP officials were excommunicated from the Church; the faithful were 
advised that voting for the MLP would be tantamount to a mortal sin; while MLP activists were denied the holy sacraments and were buried in nonconsecrated ground. Religious services of reparation were held at those public spaces that had hosted MLP meetings; this included the sprinkling of holy water. The crisis served to harden the resolve and commitment of the core MLP supporters and peace was only made in 1969, two years before the MLP was returned to power. Such high drama is still within living memory of the Maltese population, including the bulk of the current political and religious leadership.

Malta's proportional representation system with only two political parties represented in parliament is unique in Europe. With the allegiance of the voting population - just 281,000 at the latest (September 1998) election - split neatly down the middle, the difference in voter support between the two main political parties has never been more than 13,000 votes since 1971. In such a situation, a 'winner takes all' political system prevails. A candidate requires close to 3,300 votes to get elected to the 65 -seat national parliament, a small number that institutionalises close personal and patronage links between politicians and their constituents. The MLP and NP are today 'catch-all' parties, which deploy both conventional and modern techniques for both the mass and customised socialisation of citizens into loyal and unswerving party faithful. Each political party now has its own television station, radio station and newspapers; its own emblems, flags and anthems; not to mention the web of party clubs and committees spread all over the country. Information on the voting preferences of each and every Maltese is a key and active concern of the political parties. In the dense, claustrophobic social atmosphere - there are almost 2,000 persons per square kilometre - the presence, if not control, of the party is supreme and complete:

Partisanship in this polarized polity is so pervasive, ingrained and linked to class ideology and locality that preference patterns are known by street. Loyalties are strong, stable and rooted in social and family background ... [C] landidates can employ networks of family and friends to promote their election chances and to achieve greater social control over their sympathizers. They may also be able to reward their known supporters if elected. ${ }^{33}$

With the overriding influence of the Church - now keen not to involve itself in partisan politics - the Maltese are, from cradle to grave, called upon to express loyalty and commitment to any of these three 'total institutions' ${ }^{34}$ The political party thus takes on the characteristics of an ethnie, a moral community, extending the locus of empathy, trust and identification with others as if in an extended family. ${ }^{15}$ Loyalty to the state and to the ethnie may 
easily be perceived as being on a potential collision course. ${ }^{36}$ The strong sense of partisan identification and the (real or imaginary?) pursuit of partisandriven clientism may easily override any sense of national patriotism to the larger civic and territorial whole. While the casual observer may dismiss the relevance of ethnicity from Malta's socio-political landscape, a local form of bicommunalism based on political ethnicity is current; ${ }^{37}$ an implosion of the democratic Maltese state as a result of partisan ethnic fragmentation appeared possible in the constitutional crisis of 1981-84. ${ }^{38}$

In this incessant, internal struggle for loyalty and support, Maltese nationalism has lost out. The notion of the nation as an 'imagined community' becomes relevant. ${ }^{30}$ National symbols remain significant in their absence and, where identified, are quickly taken over and co-opted by partisan and/or religious motifs. A brace of poets and writers have struggled for some years to raise the spirit of nationalism, but their message has fallen on deaf ears and reads strangely hollow." Some academics have sought to emphatically announce the cultural maturation of Maltese nationalism, much like a natural development, particularly with the onset of political independence: 'Malteseness came of age ... The new state was, after all, an old nation. ${ }^{\prime 4}$ But is this not more properly appraised as an exercise in wishfulfilment? Is this not part of the unconscious obligation to defend and justify nationalism, especially de rigueur in newly independent states?

The alternative explanation propounded in this paper is that the battle for the definition of Maltese national identity has yet to commence. Malta may be an 'old nation' in a cultural sense, but politically this nation does not disclose or manifest itself, whether to the inside or to the outside world. This critical assessment can be taken forward at different analytical levels..$^{42}$ First, in specific situations, an easily manageable tourist front is resorted to by the Maltese in relation to foreigners; in this case, the language of communication is typically English. Amongst themselves, however, the Maltese develop an intricate knowledge of the partisan affiliations and loyalties of friends, family and acquaintances, effectively mapping a network of potential influence, patronage and obligation. ${ }^{43}$ In these instances, the interaction is strictly aural-oral, and the code is the Maltese language, conveniently incomprehensible to all but the locals. Second, in relation to the labour market and social stratification, the industrial working classes are Iraditionally loyal to the Labour Party, while farmers, entrepreneurs and civil servants gravitate mainly towards the Nationalist Party. In spite of a congruence of policy by the two political parties over recent decades, this occupational/social class split remains surprisingly strong. Third, macro-power structures are strongly aligned with political organisations. The latter have become well-organised networks at national, regional and local levels, down to specific streets and neighbourhoods. With 
one of the two political organisations in full control of the state apparatus at any time, the likelihood of obtaining desirable 'goods' from the state is generally seen to change in accordance with the nature and clout of individual partisan affiliation. Fourth, the cultural identity of the individual Maltese, and the perception of one's life world, remains substantially dominated by such partisan definitions. The Catholic Church, via the parish priest, provides the only escape route here, and only at a local level. Finally, the assessment of the past and the present continues to be dominated by contradictory interpretations of the relevance of historical events. As reported by an expatriate living in Malta: the Maltese are very proud of their [past] history, but apparently not of their present. ${ }^{44}$

The analyses converge: only the members of the troika - the two main political parties and the Catholic Church - loom large as anchors of identity. The 'national interest' has been sabotaged: imploded into frenzied partisanship internally; replaced by integrationism externally.

\section{SEARCHING FOR 'NATIONNESS'}

Following a major survey of the economic and democratic track record of different states, Srebrnik has argued that a society's sense of identity and self-worth, coupled by cultural values that promote trust, innovation, education and hard work, are the most important factors determining winners in a global economy. ${ }^{45}$ The statement has the features of a truism; but the spatial separateness and 'geographical precision' of small islands certainly appear a priori to bestow them with the potential for a stronger sense of self, pride and identity. ${ }^{46}$ Empirical research also suggests that small, mainly island, states are likely to have a strong democratic tradition. ${ }^{77}$ What Srebrnik fails to identify in his otherwise excellent essay is that identity is also relational; a strong sense of the self can depend on a strong sense of 'otherness'. With a benign colonial administration keen to maintain Malta primarily for strategic reasons rather than exploitative economic ones, the obvious 'other' - the colonial master - was hardly an enemy, unlike in many other colonial settings. Armed insurrections for independence, those potentially excellent schools for the formation of nationalism, were, therefore, never contemplated in Malta. If anything, it was the exact antithesis - irredentism or integration - that was seriously considered. The ties with something larger - intimated by Naipaul - have been and remain strong. ${ }^{48}$ In language, tourism, legislation, education and culture, Britain remains magnetic to the Maltese. Such a paternalist relationship - described in such strong terms as 'upside down decolonisation '4' - is shared with many of the citizens of Britain's nonsovereign overseas island territories. ${ }^{53}$ 
This is the context to Malta's application to join the EU, which, as may be expected from such a cultural context, remains gripped by debates maintaining strict partisan political lines. Malta's formal relationship with the EU goes back to April 1971, when an association agreement between Malta and the EU entered into force. Malta was the third country to enter into such an agreement with the then EU-6 and indicated an initial readiness of the island to seek favourable terms of engagement in the European economic space. The association agreement was originally meant to proceed to a customs union. However, this step was never taken, since subsequent Maltese Labour governments preferred setting up a protectionist regime that promoted indigenous industry, particularly in small-scale manufacturing, agriculture and artisanal fisheries. The policy change came with the election of the Nationalist government in 1987 on a liberalising platform. The formal application to join the EU was lodged in July 1990. In June 1993, the European Commission expressed a favourable opinion on Malta's candidature. In 1995, Malta, along with Cyprus, was informed that the formal pre-accession dialogue would start within six months of the conclusion of the next inter-governmental conference. This was duly concluded at Maastricht in 1997; but, by then, the Malta Labour Party had been elected to power and Malta's application for EU membership had been 'frozen' by the MLP. A special agreement was to be explored between Malta and the EU, a 'Switzerland in the Mediterranean' option that would defend Malta from the threats to its economy and sovereignty, which, it was argued by the MLP, would inevitably follow from full EU accession. The MLP lost power after 22 months in office: the re-elected NP reactivated Malta's application, and the country joined the 'Helsinki six' that were cleared to commence accession negotiations in December 1998. Malta started its screening of the acquis communautaire in spring 1999 and formally launched its accession negotiations in February 2000. The NP currently in power - remains enthusiastically in favour of EU membership at the earliest opportunity, and is negotiating those special conditions deemed crucial in recognition of Malta's specific circumstances. The MLP continues to argue against EU membership which, it claims, is not in Malta's best interests, since it would effectively cheat the Maltese of sovereignty and transform Malta into the EU's work or holiday destination. This could thwart locals' employment opportunities or affordable housing in their own country. There is no evident, intra-party debate: party discipline is draconian. The Church, nudged regularly to take a stand, remains defiantly, and predictably, aloof.

Against this background one may argue that it is precisely in relation to the EU that the historically elusive, external 'other' - a precondition for a nascent Maltese nationalism - may have suddenly appeared. The EU 
membership debate is replete with references to national artifacts or symbols: sovereignty, neutrality, national language, national institutions, culture, representation in European institutions, status of foreign workers, access by foreigners to local real estate, control over local fishing grounds, the replacement of the local currency (the Maltese Lira) by the Euro, the adoption of various EU common trade and security policies, promotion and protection of local agricultural products, even traditional cuisine. Possibly, a novel Maltese nationalism is being generated by and through such debates.

\section{RECONSTRUCTING IDENTITY?}

The EU-Malta issue may appear to be a classic case of an unfolding 'core-periphery' relationship. As indicated by Hache, ${ }^{51}$ changing historical, political or economic circumstances can do much to trigger an identity transformation, which can then manifest itself in a change of populist discourse.

The local debate about the pros and cons of EU membership is certainly intense, occupying much airtime on radio and television as well as columns of newsprint. But it is not exactly a 'debate': politicians, in strict discipline, toe the party line. Experts and academics, rather than being seen as independent and critical 'third parties', are often associated readily with a political stripe. Notionally, the opportunity of EU membership is a step towards a different, supra-national basis of identity, a neo-tribal 'Europeanness', which is itself the object of intensive identity-making. ${ }^{52}$ The prospect of eventual EU membership may be obliging some Maltese to think, at long last, of themselves in relation to an external other: something they have very rarely been obliged to do in their history, and certainly never in circumstances where they were alone facing 'the other' in deciding on the parameters of a complex and evolving relationship. Looking at other countries is not of much help to the Maltese here. There may be another 12 EU candidate countries, but the predicament of Malta is unique and not comparable to any of the other states.

The importance of the decision is gradually dawning; and nationalist issues appear to be coming to the fore in the debate. The concerns are clearly neither partisan political nor religiously defined: they cut across party and ideological lines and reflect the balance between isolation and integration that any sovereign state must fashion in the contemporary world. Could this identity crisis facilitate a nascent Maltese nationalism? Such a phenomenon would certainly threaten the existing, proto-ethnic duopoly that has seen regular alterations of power between the two political parties for 30 years. As if to nip this threat deftly in the bud, the MLP has declared 
that it will not accept the results of any NP government-run plebiscite on EU membership. Instead, the MLP would only accept the results of the next general election - scheduled no later than the beginning of 2004 - as the popular vote deciding in favour or against eventual EU membership for Malta. Should the NP comply, then one wonders to what extent a rigidly partisan vote would dictate Malta's European destiny, rather than the other way round.

The crisis of looming Europeanness amongst the Maltese may hinder a smooth transition to the acceptance of a paternal, benign, external other. The 'EU question' may bring about a cultural condition that has surfaced at various times in Malta's recent history: the willing incorporation into the cultural, if not economic and political, ambit of a larger state. The latter years of the reign of the Order of St John in Malta were a period of subtle but deep Gallicisation, broken only when the position and wealth of the Catholic Church in Malta came under threat from the occupying French. ${ }^{53}$ Subsequently, it was irredentism with either Britain or Italy that explained most of the local political tussles of the nineteenth and early twentieth centuries. Had the Nationalist Party's plans for Malta to join Italy in the 1930s, or the Labour Party's plans for Malta to join Britain in the $1950 \mathrm{~s}$ materialised, then, as a matter of course, Malta could have been part of the European Union since either 1958 or 1973. But what evidence of nationalism is it when the alleged nation seeks to thwart - rather than struggle for - its own political sovereignty? Can one conceive now of a novel brand of nationalism, one that is comfortable even as it seeks to diminish, rather than enhance, the autonomy and discretion of its statist and political dimension? Malta's unitary, national identity appears to be ultimately anti-nationalist externally and proto-ethnic internally. In such circumstances, appeals to sovereignty can come across as manufactured rearguard actions to brake, or replace, the movement towards regional supra-nationalism, as well as to cement the status quo of partisan gridlock.

In 1971, the showdown of Prime Minister Dom Mintoff with James Callaghan, his British counterpart, was a historical conjuncture that kindled feelings of 'one-nation' among the Maltese. Mintoff's 'maverick' foreign policy has had many detractors; but it certainly attempted to bestow some pride on the Maltese as more than the happy natives of a small and marginal state. His industrial development policy also sought a sense of "economic self-reliance' without a fortress economy. This included an ambitious programme of nationalisation of banks, airline, energy and telecommunications enterprises. The adoption of a Republican Constitution in 1974 and the complete dismantling of Malta's 'fortress economy' role by 1979 were nothing less than remarkable feats. Malta as 'one nation', however, was not to be. After 1977, the MLP policy met massive opposition 
from a variety of local interests; and the democratic crisis of the early $1980 \mathrm{~s}$ forcefully re-established the 'either-or' and 'us-them' partisan paradigm.

Gellner and Grillo have both argued that nationalist ideology emerges as a reaction to industrialisation and the uprooting of people from their local communities. ${ }^{54}$ In the Maltese island state of a paltry 316 square kilometres, which has also leapfrogged the industrialisation stage in its transition from agriculture to services, this dramatic upheaval has not happened and is inconceivable. This suggests that Malta may have an affinity with other small, compact, island states in the contemporary status of an elusive nationalism. ${ }^{55}$ The historic referendum on EU accession appears to be heading towards yet another partisan-contoured and partisan-driven contest: " $[T]$ here is no sign of political consensus on issues and little sense of a concept such as the "national interest". ${ }^{5 h}$ In such an eventuality, the Maltese are likely to confirm their standing as 'ambivalent Europeans'.57 The challenges of eventual EU membership would, thus, remain subsumed under a duopoly, certainly as far as the decision to join or not to join is concerned. Malta looks set to lumber on into the foreseeable future with the momentum of statist 'extantism' ${ }^{38}$ and the credentials of a non-nationalist, albeit sovereign, state - including the glaring and telling absence of a single national day."

\section{NOTES}

The author wishes to thank Barry Bartmann, Isabelle Calleja, Dominic Fenech, Henry Frendo, David Milne, Godfrey A. Pirotta. Saviour Rizzo and anonymous WEP reviewers for their comments on earlier drafts.

1. Statement by EU Commissioner G. Verheugen at the 'State of the Negotiations' Conference, Malta, 28 February 2001. Reproduced in Crossroads (Malta-EU Newsletter), No. 5, March $2001, \mathrm{p} .7$

2. 'The only country without a large majority [in favour of EU membership] is Malta, where only $53 \%$ of eligible respondents indicate that they would have voted in favour of EU membership' -. Applicant Countries Eurobarometer November 2001, p.3. Consult: http:/europa.eu.int/comm/public_opinion/cceb_en.htm

3. E. Gellner, Thought and Change (London: Weidenfeld \& Nicolson 1964), p.169.

4. B. Anderson. Imagined Communities: Reflections on the Origins and Spread of Nationalism (London: Verso 1983).

5. G. Baldacchino and D. Milne (eds.), Lessons from the Political Economy of Small Islands: The Resourcefulness of Jurisdiction (London: Macmillan 2000).

6. T.H. Eriksen, Ethnicity and Nationalism: Anthropological Perspectives (London: Pluto Press 1993), p.99.

7. 'Nations in waiting' is the phrase preferred by B. Bartmann, T. Bahcheli and H. Srebrnik (eds.), The Quest for Sovereignty: Unrecognized States in the International System (London: Frank Cass 2002); 'proto-nations' is a term coined by Eriksen, Ethnicity and Nationalism, p. 14; G. Gottlieb, 'Nations without States', Foreign Affairs 73/1 (1994), pp.100-112, refers 
to 'nations without states' while the reference to 'non-state nations' is by P.P. Streeten, 'The Special Problems of Small Countries', World Development 21/2 (1993), p.201.

8. Streeten, 'The Special Problems of Small Countries'.

9. On Europe of the Regions see, for example, T. Christiansen, 'Second Thoughts on Europe's Third Level: The European Union's Committee of the Regions', Publius 26/1 (1996), pp.93-166; J.G. Kellas, The Politics of Nationalism and Ethnicity (London: Macmillan 1991); and D.D. Laitin. 'The Cultural Identities of a European State', Politics and Society 25/2 (1997), pp.277-302.

10. S.P. Huntington, The Clash of Civilizations and the Remaking of World Order (New York: Simon \& Schuster 1996), pp. (37-8.

11. These two terms are attributable to R. Cohen, 'An Academic Perspective', in C. Clarke and A. Payne (eds.), Politics. Development and Security in Small States (London: Allen and Unwin 1987), p.212; and D. Beetham. 'The Future of the Nation State', in G. McLennan, D. Held and S. Hall (eds.), The Idea of the Modern State (Milton Keynes: Open University Press 1984), p.209, respectively.

12. B. Bartmann 'Patterns of Localism in a Changing Global System', in Baldacchino and Milne (eds.), Lessions from the Political Economy of Small Islands, p. 42.

13. J. Houbert. 'Settlers and Natives in Decolonisation: The Case of New Caledonia', The Round Table 74 (1985), p. 146.

14. V.S. Naipaul, The Overcrowded Barracoon and other Articles (London: Andre Deutsch 1972), p. 254.

15. Ibid., p. 270 .

16. J. Houbert, 'The Indian Ocean Creole lslands: Geopolitics and Decolonisation', Joumal of Modern African Studies 30/3 (1992), pp.465-84.

17. Consult, for example: http:/web.ai/guide/history.htm

18. S. Winchester, Outposts: Journeys to the Surviving Relics of the British Empire (Sevenoaks: Sceptre Books 1985).

19. R. Hoefte and G. Oostindie, 'The Netherlands and the Dutch Caribbean: Dilemmas of Decolonisation'. in P. Sutton (ed.), Europe and the Caribbean (London: Macmiltan 1991), pp. $71-98$.

20. W.F.S. Miles, Elections and Ethnicity in French Martinique: A Paradex in Paradise (New York: Praeger 1985).

21. D. Anckar and C. Anckar, 'Size, Insularity and Democracy', Scandinavian Political Studies 18/4 (1995), p.220.

22. J.-D. Hache, 'Towards a Political Approach to the Island Question', in G. Baldacchino and R. Greenwood (eds.), Competing Strategies of Socio-Economic Development for Small Islands (Canada: University of Prince Edward Island, Institute of Island Studies 1998). pp.60, 64-5.

23. As argued by R.R. Premdas, 'Secessionist Movements in Comparative Perspective', in R.R. Premdas, S.W.R. de A. Samarasinghe and A.B. Anderson (eds.), Secessionist Movements in Comparative Perspective (London: Pinter 1990), pp. I2-29.

24. For example, R.G. Sultana and G. Baldacchino (cds.), Maltese Society: A Sociological Inquiry (Malta: Mireva Publications 1994).

25. J. Buttigieg, 'Malta in the Throes of Modernity and Post-Modernity: A Review Article', Eronomic and Social Studies (New Series), Journal of the Faculty of Economics. Manigement \& Accountancy, University of Malta, 8 (1997), pp.53-65.

26. See M.A. Falzon, 'The Origins and Establistment of the Indian Business Community in Malta', Bank of Valletta Review (Malta) 24 (2001), pp.73-92; and A.M. Warnes and G. Patterson, 'British Retirees in Malta: Components of a Cross-National Relationship', International Journal of Population Geography 4/2 (1998), pp. I13-33, respectively.

27. R. King and J. Connell, 'Island Migration in a Changing World', in R. King and J. Connell (eds.), Small Worlds, Global Lives: Islands and Migration (London: Pinter 1999), pp.3-4.

28. J. Pirota, Fortress Colonv: The Final Act. Volume 1: 1945-54 (Malta: Studia Lditions 19871. 
29. For example, G.A. Pirotta, The Malta Public Service: 1800-1940 - The Administrative Politics of a Micro-State (Malta: Mireva 1997).

30. H. Frendo, Birth Pangs of a Nation: Manwel Dimech's Malta (1860-192I) (Malta: Mediterranein Publications 1972).

31. E.L. Zammit. A Colonial Inheritance: Maltese Perceptions of Work, Power and Class Structure with Reference to the Labour Movement (Malta: Malta University Press, 1984), p. $41, n .27$.

32. A.M. Abela, 'Values for Malta's Future: Social Change, Values and Social Policy', in Sultana and Baldacchino (cds.), Maltese Society, pp.253-70.

33. W. Hirczy, 'Explaining Near-Universal Turnout: The Case of Malta'. European Journal of Political Reseanch 27/2 (1995), pp.258, 263.

34. After E. Goffman, Asylums (Garden City NY: Basic Books 1961).

35. H.F. Srebrnik, 'Identity, Culture and Confidence in the Global Economy', in Baldacchino and Milne (eds.), Lessons from the Political Economy of Small Islands, p.57.

36. After W. Connor, Ethnonationalism: The Quest for Understanding (Princeton: Princeton University Press 1994), p.208.

37. I.V. Duchacek (ed.). Publius: The Journal of Federalism 18/2 (1988).

38. In the general elections of December 1981, the Nationalist Party secured over 50 per cent of votes, but less than 50 per cent of seats. It therefore claimed that it had the democratic mandate to govern. The Malta Labour Party, with the majority of seats secured, thought otherwise and remained in power. The NP boycotted Parliament and waged a civil disobedience campaign. See also G. Baldacchino, 'The Dynamics of Political Restructuring in Western Europe and Malta', Hyphen (Malta) 6 (1989), pp.98-116.

39. Anderson, Imagined Communities, emphasis added.

40. Maltese novelists and poets such as Achille Mizzi, Alfred Massa and Frans Sammut articulated the excitement and enthusiasm of a newly independent people in their publications during the late $1960 \mathrm{~s}$ and early 1970s. However. this 'up-beat' mood was soon eclipsed by more sombre subject matter.

41. H. Frendo, 'Maltese Colonial Identity: Latin Mediterranean or British Empire'?' in V. Mallia-Milanes (ed.), The British Colonial Experience: 1800-1964: The Impact on Maltese Society (Malta: Mireva 1988), p.210.

42. As also proposed by T.H. Eriksen, $U s$ and Them in Modern Societies: Ethnicity and Nationalism in Mauritius. Trinidad and Beyond (Oslo: Scandinavian University Press 1992), p.24.

43. J. Boissevain Friends of Friends: Networks, Manipulations and Coalitions (Oxford: Blackwell 1974).

44. Statet by Ms Heiga Ellul, a prominent German business woman married to a Maltese, at a Round Table discussion on the work ethic organised by the Workers' Participation Development Centre of the University of Malta - 15 May 2002.

45. Srebrnik, "Identity, Culture and Confidence in the Global Economy', p.68.

46. D. Weale. 'Islandness', Island Journal 8 (Canada: University of Prince Edward Island, Institute of Island Studies 1992), pp.81-2.

47. Anckar and Anckar, 'Sizc. Insularity and Democracy'.

48. Naipaul, The Overcrowded Barracoon.

49. Hoctte and Oostindie. 'The Netherlands and the Dutch Caribbean'. p.93.

50. Winchester, Outposts.

51. Hache, 'Towards a Political Approach to the Island Question'.

52. P. Schlesinger, 'Europeanness: A New Cultural Battlefield?', in J. Hutchinson and A.D. Smith (eds.). Nationalism (Oxford: Oxford University Press 1994), pp.316-25; B. Laffan, 'European Union: A Distinctive Model of Internationalisation?', European Integration Online Papers 1/18 (1997) hup:/eiop.or.at/eiop/lexte/1997-018a.htm.

53. V. Mallita-Milanes. 'The (ienesis of Maltese Nationalism', in Mallia-Milanes (ed.), The British Colonial Experience, pp. 1-18.

54. E. Gellner Nations and Nationalism (Oxford: Blackwell 1983), and R. Grillo, 
'Introduction', in idem (ed.). 'Nation' and 'State' in Europe (London: Academic Press 1980), pp.1-18.

55. G. Baldacchino, 'The Other Way Round: Manufacturing as an Extension of Services in Small States", Asia Pacific Viewpoint 39/3 (1998), pp.267-79.

56. Commentary on Malta from 2002 Report on Candidate Countries Progress towards EU Accession, released by UNICE, Brussels, 6 June 2002. Reported in The Times (Malsa, Progress Press), 7 June 2002, pp. 1, 14.

57. J. Mitchell, Ambivalent Europeans: Ritual, Memory and the Public Sphere in Malta (London: Routledge 2001).

58. After B. Schaffer, 'The Politics of Dependence', in P. Selwyn (ed.). Development Policy in Small Countries (London: Croom Helm 1975), p.25.

59. Malta has five national days which, in themselves, reflect the competing claims for national importance of historic events which remain associated with one particular political party; or, in an act of desperation, a resort to a day of some religious or populist (and therefore national?) significance. 